\title{
Progress in Chemical Constituents and Bioactivities of Broussonetia papyrifera (L.) Vent
}

\author{
Fang $\mathrm{Li}^{a}{ }^{a}$ Tingyu Wen, ${ }^{a}$ and Jifeng $\mathrm{Liu}^{*, a, b}$ \\ ${ }^{a}$ School of Pharmaceutical Sciences; Institute of Drug Discovery and Development; Key Laboratory \\ of Advanced Pharmaceutical Technology, Ministry of Education of China; \\ Zhengzhou University, Zhengzhou, Henan 450001, China \\ ${ }^{b}$ Collaborative Innovation Center of New Drug Research and Safety Evaluation, Zhengzhou, \\ Henan 450001, China \\ Email: liujf2009y@126.com (J. L.)
}

\begin{abstract}
Broussonetia papyrifera (B. papyrifera) is a deciduous tree of the genus Broussonetia of Moraceae. Its roots, stems, leaves, skins, fruits and seeds can be used as folk medicine. Modern technology research showed that the B. papyrifera was rich in flavonoids and triterpenoids, and its components exhibited anti-proliferation, antibacterial, anti-oxidation, cytotoxicity, enzyme inhibition and other activities. In this paper, we summarized the progress in the chemical constituents and bioactivities of $B$. papyrifera since 2000 to provide ideas for the medicinal development prospects of $B$. papyrifera.
\end{abstract}

Keywords Broussonetia papyrifera, chemical constituents, bioactivities, progress

\section{Introduction}

Broussonetia papyrifera (L.) Vent, belonging to the deciduous tree of the genus Broussonetia of Moraceae, is also known as paper mulberry. There are five species in the world, which distributed mainly in eastern Asia and the Pacific islands. Four species distributed in the Yellow River, the Yangtze River, the Pearl River and Taiwan in China, including B. papyrifera, B. kazinoki, B. kaempferi, and B. kurzii. B. papyrifera is a highly valued plant in China. Its leaves, roots, barks and fruits are traditional Chinese medicines with multiple bioactivities. The roots can be used as diuretics, tonics and inhibitors; ${ }^{[1]}$ the branches can be used to treat rubella, red eyes and swelling, and urinary dysfunction; the leaves have the effects of clearing away heat and detoxifying, cooling blood and diuresis, ${ }^{[2]}$ and can be used to treat blood vomiting, dysentery, hemorrhoids, et al.; the fruits are also known as Fructus Broussonetiae, which have the functions of tonifying kidney, clearing liver, eyesight and diuretic, ${ }^{[3,4]}$ and can be used to treat fatigue, severe fever, and dizziness. ${ }^{[5]}$ Modern pharmacological studies revealed that $B$. papyrifera had the activities of anti-inflammatory, ${ }^{[6]}$ anti-tumor, ${ }^{[7]}$ anti-fungal, ${ }^{[8]}$ anti-hepatic toxicity, ${ }^{[9,10]}$ antioxidation, ${ }^{[11]}$ enhancing immune function, ${ }^{[12]}$ improving endoplasmic reticulum stress in the Alzheimer's disease model. ${ }^{[13]}$

Herein, we utilized "chemical constituents of Broussonetia papyrifera" and "activities of Broussonetia papyrifera" as keywords to search for relevant literatures and books in SciFinder, Web of Science, China National Knowledge Infrastructure academic database and website, and has summarized chemical constituents and bioactivities of $B$. papyrifera since 2000 .

\section{Chemical Constituents}

Since 2000, researchers have isolated $\mathbf{7 2}$ compounds from various parts of the $B$. papyrifera, including flavonoids, terpenoids, phenylpropanoids, anthraquinones and organic acids.

Flavonoids and their glycosides in B. papyrifera distributed widely in barks, which were identified as kazinol B (1), 7,4'- dihydroxy-3'-prenylflavan (2), 7,3'-dihydroxy-4'-methoxyflavan(3), kazinol A (4), 3'-(3-methylbut-2-enyl)-3',4',7-trihydroxyflav ane (5), broussochalcone A (6), 5,7,3',4'-tetrahydroxy-3methoxy-8-geranylflavone (7), 5,7,3',4'-tetrahydroxy-3-methoxy -8,5'-diprenylflavone (8), uralenol (9), papyriflavonol A (10) and broussoflavonol B (11). Above-mentioned compound 3 was isolated from the barks for the first time and compounds 7 and 8 were two new prenylflavones. ${ }^{[14-16]}$ Besides, broussochalcone $B$ (12), 3,4-dihydroxyisolonchocarpin (13), 4-hydroxyisolonchocarpin (14), kazinol E (15), 8-(1,1-dimethylallyl)-5'-(3-methylbut2-enyl)-3',4',5,7-tetrahydroxyflanvonol (16), brossoflurenone $A$ (17) and brossoflurenone $B(18)$ were isolated from roots, in which compounds 17 and 18 were two novel benzofluoreneones. ${ }^{[17]}$

Besides the above-mentioned compounds, flavonoids and their glycosides were also isolated from the fruits and leaves of $B$. papyrifera, which were named apigenin (19), apigenin-7-O$\beta$ - $D$-glucopyranoside (20), broupapyrin A (21), cosmosiin (22), luteolin-7-O- $\beta$ - $D$-glucopyranoside (23), and apigenin-6-C- $\beta$ - $D$ glucopyranside (24). Compound 21 was a new isoprenylated flavonol ${ }^{[18]}$ and 24 was isolated from the leaves for the first time. ${ }^{[19,20]}$ Their structures are shown in Figure 1.

\section{Triterpenoids and their glycosides}

Since 2000 , nine triterpenoids have been isolated from $B$. papyrifera, named lupeol acetate (25), (3 3 )-3-(acetyloxy)eupha-7,25-dien-24-one (26), (3 $\beta, 24 R)$-3-(acetyloxy)-eupha-7, 25-dien-24-ol (27), (3ß,24S)-eupha-7,25-diene-3,24-diol (28), $(3 \beta, 24 R)$-eupha-7,25-diene-3,24-diol (29), 3 $\beta$-acetoxy-

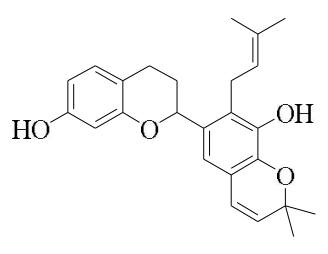

1<smiles>CC(C)=CCC1C=C([C@H]2C=Cc3ccc(O)cc3O2)C=CC1O</smiles> 
<smiles>COc1ccc(C2CCc3ccc(O)cc3O2)cc1O</smiles><smiles>CC(C)=CCc1cc(C2CCc3ccc(O)cc3O2)cc(O)c1O</smiles><smiles>[R]c1cc(-c2oc3c([N])c(O)c([R])c(O)c3c(=O)c2[R])cc(O)c1O</smiles>

$7 \mathrm{R}=\mathrm{H}, \quad \mathrm{R}_{1}=$ geranyl, $\mathrm{R}_{2}=\mathrm{H}$

$9 \mathrm{R}=$ prenyl, $\mathrm{R}_{1}=\mathrm{H}, \quad \mathrm{R}_{2}=\mathrm{H}, \quad \mathrm{R}_{3}=\mathrm{H}$

$10 \mathrm{R}=$ prenyl, $\mathrm{R}_{1}=\mathrm{H}, \quad \mathrm{R}_{2}=$ prenyl, $\mathrm{R}_{3}=\mathrm{H}$

$11 \mathrm{R}=\mathrm{H}, \quad \mathrm{R}_{1}=$ prenyl, $\mathrm{R}_{2}=$ prenyl, $\mathrm{R}_{3}=\mathrm{CH}_{3}$<smiles>CC(C)=CCc1cc(/C=C/c2ccc(O)cc2)c(O)cc1O</smiles>

12<smiles>C=CC(C)(C)c1cc2c(cc1O)OC(c1cc(O)c(O)c(CC=C(C)C)c1CC=C(C)C)CC2</smiles>

15<smiles></smiles>

17<smiles>[R]c1cc(O)c2c(=O)cc(-c3ccc(O)cc3)oc2c1</smiles>

$19 \mathrm{R}=\mathrm{H}$

$20 \mathrm{R}=\mathrm{Glc}$<smiles>[R]c1cc(-c2cc(=O)c3c(O)cc(Cl)cc3o2)ccc1O</smiles>

$22 \mathrm{R}=\mathrm{H}$

$23 \mathrm{R}=\mathrm{OH}$

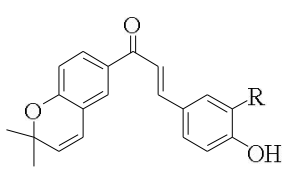

$13 \mathrm{R}=\mathrm{OH}$ $14 \mathrm{R}=\mathrm{H}$<smiles>CC(C)=CCc1cc(-c2oc3c(C(C)(C)C)c(O)cc(O)c3c(=O)c2O)cc(O)c1O</smiles>

16<smiles></smiles>

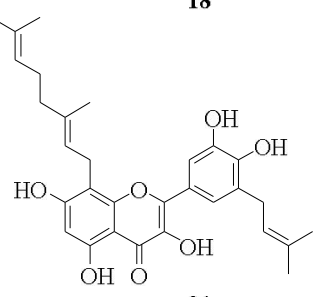

21

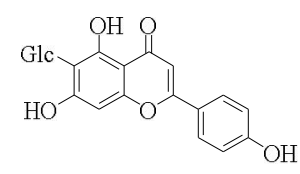

24
Figure 1 Chemical structures of flavonoids isolated from $B$. papyrifera.
tirucalla-7-en-24S,25-diol (30), oleanolic acid (31), augustic acid (32). Among them, compounds 26-30 were five new tetracyclic triterpenoids. ${ }^{[14,21-23]}$ The structures are shown in Figure 2

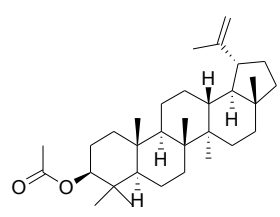

25

27

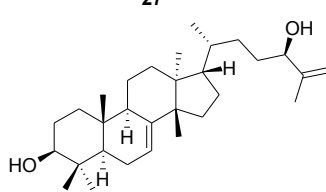

29

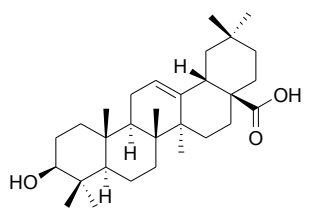

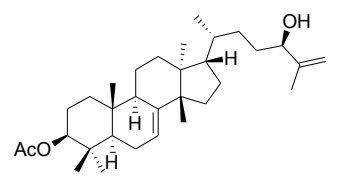<smiles>C=C(C)C(=O)CC[C@H](C)[C@@]1(C)CC[C@]2(C)C3=CC[C@H]4[C@H](C)[C@@H](OC(C)=O)CC[C@]4(C)[C@H]3CC[C@@H]21</smiles>

26<smiles>C=C(C)[C@H](O)CC[C@H](C)[C@H]1CC[C@]2(C)C3=CC[C@H]4[C@@H](C)[C@H](O)CC[C@]4(C)[C@H]3CC[C@H]12</smiles>

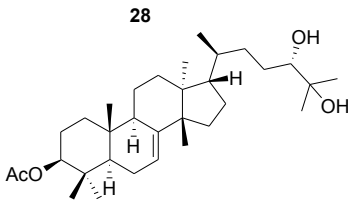

30

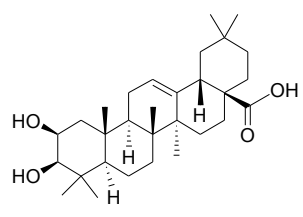

32
Figure 2 Chemical structures of triterpenoids isolated from $B$. papyrifera.

\section{Phenylpropanoids}

Eight coumarins and four lignans have been isolated from $B$. papyrifera, named 6,7-dimethoxycoumarin (33), (+)-marmesin (34), (+)-(2'S,3'R)-3-hydroxyl marmesin (35), (+)-pinoresinol4'-O- $\beta$ - $D$-glucopyranosyl-4"-O- $\beta-D$-apiofuranoside (36), liriodendrin (37), lariciresinol-9-O- $\beta$ - $D$-glucopyranoside (38), syringaresinol-4-O- $\beta$ - $D$-glucopyranoside (39), 3,4',5'-trihy- droxy-5 methoxy-6H-benzo [c] chromen-6-one (40), alternariol 4'-Omethyl ether (41), alternariol 5-O-methyl ether (42), alternariol (43), alternuene (44). Compounds 34 and 35 were isolated from the barks for the first time, compound $\mathbf{3 6}$ was a new lignan, compounds $\mathbf{3 8}$ and $\mathbf{3 9}$ were lignans isolated from the leaves for the first time.$^{[20,21,24,25]}$ Their structures are shown in Figure 3.

\section{Organic acids and their esters}

Nine organic acids and their esters have been isolated from B. papyrifera, which were identified as daucosterol palmitate (45), palmitic acid ethyl ester (46), palmitic acid (47), linoleic acid (48), 9-octadecenoic acid (49), 8,11-octadecadienoic acid<smiles>COc1cc2ccc(=O)oc2cc1O</smiles>

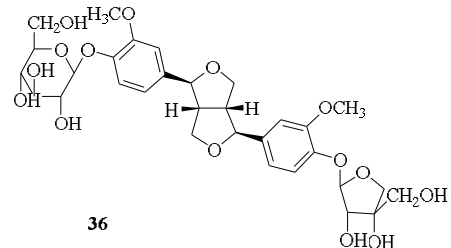

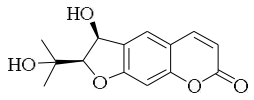

35<smiles>COc1ccc([C@H]2OC[C@H]3COC[C@@H]23)cc1OC</smiles>

37 

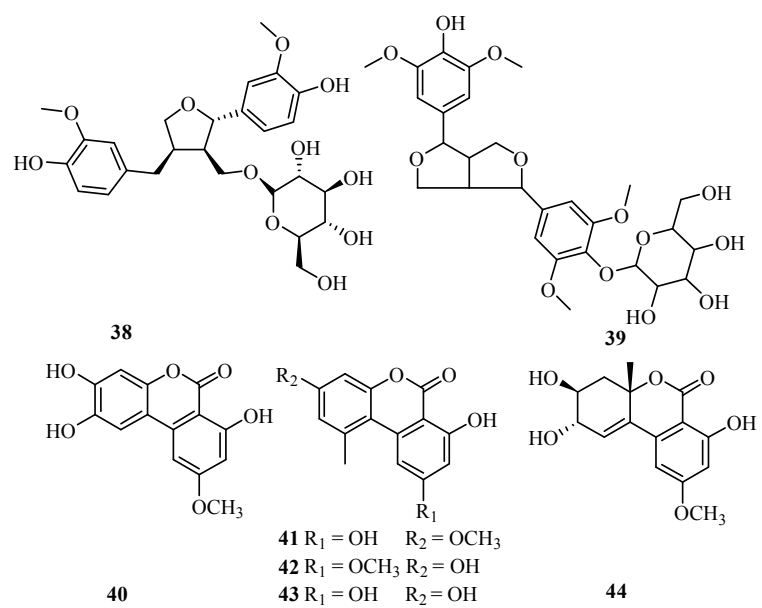

Figure 3 Chemical structures of phenylpropanoids isolated rom $B$. papyrifera.

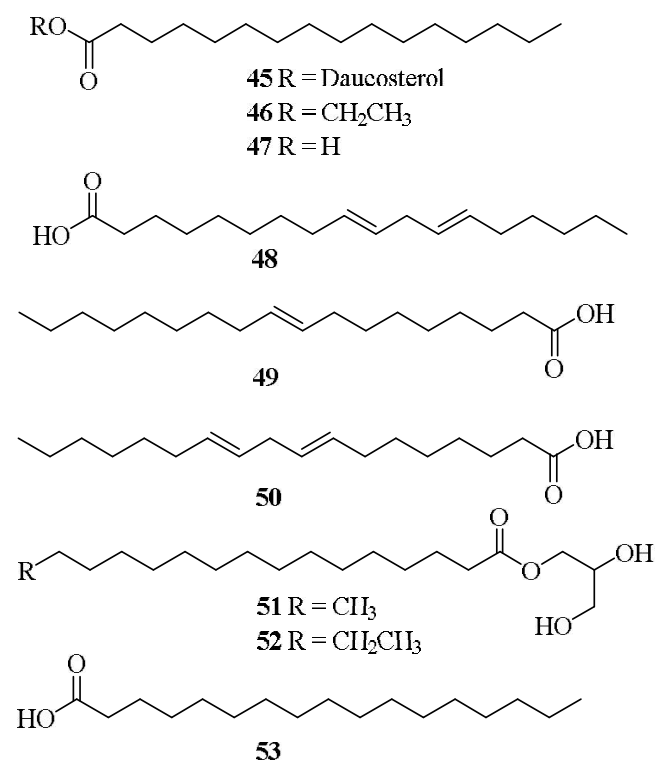

Figure 4 Chemical structures of organic acids and their esters isolated from $B$. papyrifera.

(50), $\alpha$-monopalmitin (51), monoheptadecanoin (52) and heptadecanoic acid (53). Among them, compounds 46, 47 and 48 were isolated from the fruits for the first time, compounds $\mathbf{5 1}$ and $\mathbf{5 2}$ were isolated from the barks firstly, and compound $\mathbf{5 3}$ was isolated from the leaves for the first time. ${ }^{[1,21,25,26]}$ Their structures are shown in Figure 4.

\section{Other compounds}

Some other types of compounds were also isolated from $B$. papyrifera, including anthraquinones, alkaloids, sterols, aryl propanes, lactones, which were identified as physcion (54), $\beta$-daucosterol (55), phytol (56), ${ }^{[19]}$ altertoxin IV (57), altersolanol A (58), altersolanol C (59), altertoxin I (60), ergosta-4,6,8,22tetraen-3-one (61), ${ }^{[24]} \beta$-sitosterol (62), broussonin A (63), broussonin $B(64)$, broussonin $F(65), 2$ '-deoxyadenosine (66), thymidine (67), 2'-deoxyuridine $(68),{ }^{[21,25]} \delta$-tocopherol (69), $3,5,4$ '-trihydroxy-bibenzyl-3-O- $\beta$ - $D$-glucoside $(70),\{(4 R, 5 S, 10 S)$ -8,9,10-trihydroxy-4-[3'-methoxy-4'-hydroxyphenyl]-1,6-dioxaspi ro $[4,5]$ decan-2-one\} (71) and 4-hydroxyacetophenone (72). ${ }^{[19-20,25]}$ Their structures are shown in Figure 5.<smiles>COc1cc(O)c2c(c1)C(=O)c1cc(C)cc(O)c1C2=O</smiles>

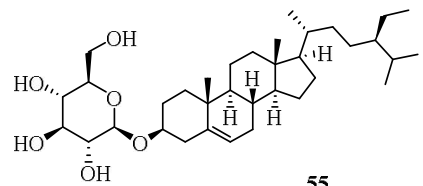

54<smiles>CC(=CCCC(C)CCCC(C)CCCC(C)C)CCO</smiles>

56<smiles>O=C1C=CC2=C3C(O)C=CC2=C(O)C=CC3C(O)C1O</smiles><smiles>[R]C1C2=C(C(=O)c3cc(Cl)cc(O)c3C2=O)[C@H](O)[C@@H](C)[C@@H](C)[C@H]1[CH]</smiles>

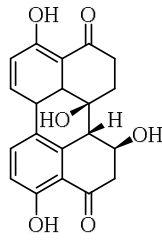

57

$58 \mathrm{R}=\mathrm{OH}$ 6<smiles>CC(C)C(C)/C=C/C(C)C1CCC2=C3C=CC4=CC(=O)CCC4(C)C3CCC21C</smiles>

61<smiles>COc1ccc(CCCc2ccc(O)cc2)c(O)c1</smiles>

63<smiles>COc1cc(CCCc2ccc(O)cc2OC)ccc1O</smiles>

65

67<smiles>Cc1cn(C2C[C@H](O)C(CO)O2)c(=O)[nH]c1=O</smiles><smiles>CCC(CCC[C@H](C)C1CCC2C3CC=C4CC(O)CCC4(C)C3CCC2[C@@H]1C)C(C)C</smiles>

62<smiles>COc1cc(O)ccc1CCCc1ccc(O)cc1</smiles>

64<smiles>Nc1ncnc2c1ncn2[C@@H]1C[C@H](O)[C@@H](CO)O1</smiles>

66<smiles>O=c1ccn(C2C[C@H](O)C(CO)O2)c(=O)[nH]1</smiles>

68<smiles>Cc1cc(O)cc2c1OC(C)(CCCC(C)CCCC(C)CCCC(C)C)CC2</smiles>

69<smiles>Oc1cccc(CCc2ccc(O)cc2O)c1</smiles><smiles>COc1cc([C@H]2CC(=O)OC2(O)C2C(O)C3OCC2C3O)ccc1O</smiles><smiles>CC(=O)c1ccc(O)cc1</smiles>

72
Figure 5 Chemical structures of other compounds isolated from $B$. papyrifera.

\section{Bioactivities}

It is rich in flavonoids and terpenoids in B. papyrifera, and these compounds possess widely bioactivities. For example, previous studies revealed that apigenin had anti-tumor, anti-viral, anti-bacterial activities, ${ }^{[27]}$ alkaloids had cytotoxicity. ${ }^{[28]}$ Monocyclic monoterpenoid had the effect of treating prostatitis. ${ }^{[29-32]}$

\section{Antioxidant activity}

Pang et al. ${ }^{[26]}$ studied the chemical constituents of scorpion fatty oil (FOFB) and its effects on plasma lipids. The main compound 8,11-octadecadienoic acid (50), which was a potent 
natural antioxidant in FOFB, inhibited the production of NO by LPS-induced RAW264.7 macrophages. ${ }^{[33]}$

Han et al. ${ }^{[34]}$ used ultrasound-assisted extraction to extract B. papyrifera fruits (BPP). Then, BPP was purified, and three purified fractions (designated BPP-1, BPP-2 and BPP-3) were obtained for further physicochemical properties. In vitro activity revealed that BPP-3 $\left(\mathrm{IC}_{50}=0.57 \mu \mathrm{g} / \mathrm{mL}\right)$ and BPP-1 $\left(\mathrm{IC}_{50}=0.54\right.$ $\mu \mathrm{g} / \mathrm{mL}$ ) had the better antioxidant activity, compared with BPP-2 $\left(\mathrm{IC}_{50}=0.86 \mu \mathrm{g} / \mathrm{mL}\right)$.

\section{Antibacterial activity}

Li et al. ${ }^{[14]}$ obtained nine compounds from the EtOAc fraction of the mulberry barks. In vitro antibacterial test showed that 7,4'-dihydroxy-3'-prenylflavan (2) and oleanolic acid (31) exhibited stronger antimicrobial activity against Actinomyces naeslundii ATCC $12104(1.95,1.95 \mu \mathrm{g} / \mathrm{mL})$ and Porphyromonas gingivalis ATCC $33277(3.90,1.95 \mu \mathrm{g} / \mathrm{mL})$ than the positive control [A. naes/undii ATCC $12104(3.9 \mu \mathrm{g} / \mathrm{mL}) ; P$. gingivalis ATCC $33277(7.80 \mu \mathrm{g} / \mathrm{mL})]$.

Sohn et al. ${ }^{[35]}$ reported that a prenylated flavonol compound Papyriflavonol A (Pap A) (10) was isolated from the mulberry roots, and evaluated its antimicrobial activity. The results revealed that the minimum inhibitory concentration (MIC) of Pap A against Candida albicans and Saccharomyces cerevisiae was between $10 \mu \mathrm{g} / \mathrm{mL}$ and $25 \mu \mathrm{g} / \mathrm{mL}$, and its antifungal activity was mediated by its ability to disrupt cell membrane integrity. In addition, Pap A had a lower toxic effect than amphotericin B, and for the tested strains (MIC $=10-25 \mu \mathrm{g} / \mathrm{mL}$ ), the hemolysis ratio of human erythrocytes was less than $5 \%$.

Geng et al. ${ }^{[16]}$ reported that flavonols in $B$. papyrifera showed significantly anti-oral microbial activity in vitro. Among them, compound 5,7,3',4'-tetrahydroxy-3-methoxy-8,5'-diprenyIflavone (8) was more effective in suppressing Actinomyces naeslundii and Porphyromonas gingivalis $(\mathrm{MIC}=1.95 \mathrm{ppm})$ than the positive control, triclosan.

\section{Anti-proliferative activity}

Guo et al. ${ }^{[15]}$ isolated and purified six compounds from EtOAc extract of mulberry bark and studied their biological activities. Cell activity revealed that the compounds broussochalcone A (6), 5,7,3',4'-tetrahydroxy-3-methoxy-8,5'-diprenylflavone (8), uralenol (9), papyriflavonol A (10), and broussoflavonol B (11) showed significant anti-proliferative effects on ER-positive breast cancer MCF-7 cells in vitro, and the compounds 5,7,3', 4'-tetrahydroxy-3-methoxy-8,5'-diprenylflavone $\left(\mathrm{IC}_{50}=4.41 \mu \mathrm{M}\right)$ and broussoflavonol $\mathrm{B}\left(\mathrm{IC}_{50}=4.19 \mu \mathrm{M}\right)$ were more effective than the positive control, icaritin. In an established human breast cancer BCAP-37 xenograft BALB/c nude mice model, compounds 8 and 11 reduced tumor growth significantly at the concentrations of $1 \mu \mathrm{M}$. Both compounds reduced ERK phosphorylation. Western blot indicated the compounds down-regulated strongly expression concentrations of estrogen receptor- $\alpha$ (ER- $\alpha$ ).

Liu et al. ${ }^{[36]}$ reported that the effects of flavonoids on the proliferation of mouse epidermal stem cells in vitro. The results found that flavonoids inhibited cell proliferation and it was related to the concentration of compounds. When the concentrations of flavonoids were between $5 \mu \mathrm{g} / \mathrm{mL}$ and 10 $\mu \mathrm{g} / \mathrm{mL}$, the inhibition rate of epidermal stem cells reached $50 \%$, and the high correlation between inhibitory effect and dosage of flavonoids on cells at $2 \mathrm{~d}\left(r_{2 \mathrm{~d}}=-0.826\right), 4 \mathrm{~d}\left(r_{4 \mathrm{~d}}=-0.810\right)$ and 6 $d\left(r_{6 d}=-0.750\right)$, respectively.

\section{Cytotoxic activity}

Ran et al. ${ }^{[20]}$ determined the cytotoxicity of the compounds, which were isolated from the leaves by MTT method. They found that the compounds (+)-pinoresinol-4'-O- $\beta$ - $D$-gluco-
pyransyl-4"-O- $\beta-D$-apiofuranoside (36), liriodendrin (37), and apigenin-6-C- $\beta$ - $D$-glycopyranside (24) had different degrees of inhibitory activity on HepG-2 cell line, with the $\mathrm{IC}_{50}$ at 17.19 , 14.56 and $19.53 \mu \mathrm{g} / \mathrm{mL}$, respectively.

Zhang et al. ${ }^{[24]}$ reported that a new compound altertoxin IV (57) together with nine known compounds were isolated from the ethyl acetate extract of a culture of the endophytic fungus Alternaria species $G 7$ in $B$. papyrifera by means of bioassay-guided fractionation. The compounds had cytotoxic activities against three cancer cell lines (A549, MG-63 and SMMC-7721), of which the compound 3,4',5'-trihydroxy-5methoxy-6H-benzo [c] chromen-6-one (40) showed significant cytotoxic activity with $\mathrm{IC}_{50}$ values of $1.47,2.11$ and $7.34 \mu \mathrm{g} / \mathrm{mL}$, respectively. However, the compound altersolanol A (58) showed significant cytotoxic activity against cell lines MG-63 $\left(\mathrm{IC}_{50}=0.53 \mu \mathrm{g} / \mathrm{mL}\right)$ and SMMC-7721 $\left(\mathrm{IC}_{50}=2.92 \mu \mathrm{g} / \mathrm{mL}\right)$.

\section{Enzyme inhibition activity}

Ryu et al. ${ }^{[17]}$ showed that twelve polyphenols were isolated from the chloroform extract of the roots of $B$. papyrifera. Among them, the most potent inhibitor, papyriflavonol $A(10)\left(\mathrm{IC}_{50}=2.1\right.$ $\mu \mathrm{M})$ had slightly higher $\alpha$-glucosidase inhibitory activity than $\alpha$-glucosidase inhibitor deoxynojirimycin $\left(\mathrm{IC}_{50}=3.5 \mu \mathrm{M}\right)$, and the novel $\alpha$-glucosidase inhibitors brossoflurenone A (17) $\left(\mathrm{IC}_{50}\right.$ $=27.6 \mu \mathrm{M})$, brossoflurenone $\mathrm{B}(\mathbf{1 8})\left(\mathrm{IC}_{50}=33.3 \mu \mathrm{M}\right)$ were similar in activity to sugar-derived $\alpha$-glucosidase inhibitors voglibose $\left(\mathrm{IC}_{50}=23.4 \mu \mathrm{M}\right)$. Further studies by Ryu et al. ${ }^{[37]}$ found that the compound broussochalcone $A(6)\left(I C_{50}=5.8 \mu \mathrm{M}\right)$ and the compound 3,4-dihydroxyisolonchocarpin (13) $\left(\mathrm{IC}_{50}=\right.$ $7.7 \mu \mathrm{M}$ ) were the major contributors to the inhibition of xanthine oxidase, and the compound broussochalcone $A$ was more effective.

Lou et al. ${ }^{[18]}$ reported that a new isoprenylated flavonol was isolated from the branches of $B$. papyrifera, and this compound broupapyrin A (21) showed significant inhibitory effect on PTP1B with an $\mathrm{IC}_{50}$ value of $0.83 \pm 0.30 \mu \mathrm{M}$.

Park et al. ${ }^{[38]}$ evaluated the inhibitory activity of Broussonetia papyrifera-derived polyphenols against 3-chymotrypsinlike and papain-like coronavirus cysteine proteases. The results showed papyriflavonol A (10) was the most potent inhibitor of $\mathrm{PL}^{\text {pro }}$ with an $\mathrm{IC}_{50}$ value of $3.7 \mu \mathrm{M}$.

\section{Conclusion and perspective}

$B$. papyrifera as a high medicinal value plant is widely distributed in China, and its leaves, roots, barks and fruits can be applied in clinical practice. The chemical compositions of $B$. papyrifera mainly including flavonoids and terpenoids are complex and diverse, the diversity of its chemical ingredients leads to a wide range of pharmacological activities, which are antioxidant, antibacterial, anti-proliferative, cytotoxic, enzyme inhibition and other activities. It should be pointed out that the researchers focus mainly on finding compounds with better activity in $B$. papyrifera, but do not conduct in-depth research on the mechanism of their action, which is difficult to explain the material basis of clinical application of $B$. papyrifera, and greatly limits the construction of trees. For more rationally and effectively to develop resources in B. papyrifera, researchers should perform further research on its chemical constituents, bioactivities and the mechanism of action in the future.

\section{Acknowledgement}

This work was supported by the Science and Technology Tackling Project of Henan Science and Technology Department (No. 182102310063). 


\section{References}

[1] Zhang, P. C.; Wang, S.; Wu, Y.; Chen, R. Y.; Yu, D. Q. J. Nat. Prod. 2001, 64, 1206.

[2] Cao, J. H.; Huang, X. Z.; Chen, S. Q. Chin. Med. Res. Clin. 2004, 2, 8.

[3] Peng, X. J.; Shen, S. H. Acta Bot. Sin. 2018, 53, 372.

[4] Jiang, Q. Q.; Liang, S. Y.; Li, Z. Q.; Li, Y. H.; Ma, M.; Wu, Z. Z. J. Henan Univ. Sci. Technol. (Med. Sci.) 2018, 36, 236.

[5] Pharmacopoeia Commission of the People's Republic of China, Pharmacopoeia of People's Republic of China, Beijing, 2010, p. 315.

[6] Lin, L. W.; Chen, H. Y.; Wu, C. R.; Liao, P. M.; Lin, Y. T.; Hsieh, M. T.; Ching, H. Biosci. Biotechnol. Biochem. 2008, 72, 2377.

[7] Sohn, H. Y.; Son, K. H.; Kwon, C. S.; Kwon, G. S.; Kang, S. S. Phytomedicine 2004, 11, 666.

[8] Li, Z. M.; Chen, J. J.; Yan, M. H. Med. Plant 2010, 1, 33.

[9] Pang, S. Q.; Wang, G. Q.; Huang, B. K.; Qin, L. P. Chin. Med. Mat. 2007, 30, 826

[10] Guo, M. X.; Wang, M. L.; Deng, H.; Zhang, X. T.; Wang, Z. Y. Eur. J. Pharmacol. 2013, 714, 56.

[11] Pang, S. Q.; Wang, G. Q.; Qin, L. P.; Huang, B. K.; Zhang, Q. Y. J. Chin. Med. Master. 2006, 29, 262.

[12] Huang, W.; Chen, S. H.; Liu, Y.; Liu, Y. F. Chin. J. Mod. Appl. Pharm. 2017, 34, 8.

[13] Li, Y. H.; Hu, L.; Wu, Z. Z.; Yu, Z. L.; Cao, M. Q.; Sun, K. H.; Jin, Y. Neural Regen. Res. 2011, 6, 2325.

[14] Li, Z. M.; Chen, J. J.; Yan, M. H. J. Anhui Agr. Sci. 2010, 38, 7288.

[15] Guo, F. J.; Feng, L.; Huang, C.; Ding, H. X.; Zhang, X. T.; Wang, Z. Y.; Li, Y. M. Phytochem. Lett. 2013, 6, 331.

[16] Geng, C. A.; Yan, M. H.; Zhang, X. M.; Chen, J. J. Nat. Prod. Bioprosp. 2019, 9, 139.

[17] Ryu, H. W.; Lee, B. W.; Ryu, Y. B.; Jung, S.; Lee, W. S.; Park, K. H. J. Agr. Food Chem. 2010, 58, 202.

[18] Lou, Y.; Su, S. Y.; Li, Y. N.; Lei, C.; Li, J. Y.; Hou, A. J. Chin. J. Chin. Mater. Med. 2019, 44, 88.

[19] Pang, S. Q.; Wang, G. Q.; Sun, A. J. J. Chin. Pharm. 2016, 27, 4384.

[20] Ran, X. K.; Wang, X. T.; Liu, P. P.; Chi, Y. X.; Wang, B. J.; Dou, D.
Q.; Kang, T. G.; Xiong, W. Chin. J. Nat. Med. 2013, 11, 269.

[21] Zhong, H. T.; Zhang, X. Q.; Wang, M. K. Nat. Prod. Res. Dev. 2011, 23, 661.

[22] Zhong, H. T.; Li, F.; Chen, B.; Wang, M. K. Helv. Chim. Acta 2011 94, 2061.

[23] Zhong, H. T.; Li, F.; Chen, B.; Wang, M. K. Nat. Prod. Res. Dev. 2012, 24, 147.

[24] Zhang, N. D.; Zhang, C. Y.; Xiao, X.; Zhang, Q. Y.; Huang, B. K. Fitoterapia 2016, 110, 173

[25] Li, H. W.; Zheng, X. K.; Feng, W. S. Mod. Tradit. Chin. Med. Mater. Med. 2016, 18, 82.

[26] Pang, S. Q.; Wang, G. Q.; Jin, X. Q.; Sun, A. J.; Lin, J. S.; Diao, Y. Am. J. Plant Sci. 2016, 7, 446.

[27] Lin, L. W.; Xin, Q. Chin. Trop. Med. 2012, 12, 1023.

[28] Pang, S. Q.; Wang, G. Q.; Lin, J. S.; Diao Y.; Xu, R. A. Pharmaceut. Biol. 2014, 52, 1315.

[29] Chen, S. Q.; Huang, X. Z.; Cui, Y.; Wang, L. Pharmacol. Clin. Chin. Mater. Clin. Med. 2006, 22, 110.

[30] Cui, C.; Chen, S. Q.; Wei, Y. L. Henan Sci. 2009, 27, 40

[31] Feng, W. S.; Li, H. W.; Zheng, X. K.; Kuang, H. X.; Chen, S. Q.; Wang, Y. Z.; Zang, X. Y. Acta Pharm. Sin. 2008, 43, 173.

[32] Feng, W. S.; Li, H. W.; Zheng, X. K.; Chen, S. Q. Chin. Chem. Lett 2007, 18, 1518.

[33] Zhao, H. F.; Huang, L. Z.; Qin, L. P.; Huang, B. K. J. Med. Plants Res. 2011, 5, 6407.

[34] Han, Q. H.; Wu, Z. L.; Huang, B.; Sun, L. Q.; Ding, C. B.; Shu, Y.; Zhang, Z. W. Int. J. Biol. Macromol. 2016, 92, 116.

[35] Sohn, H.Y.; Kwon, C. S.; Son, K. H. J. Microbiol. Biotechnol. 2010 20, 1397.

[36] Sun, G. Y. Ph.D. Dissertation, Shanxi University, Shanxi, China, 2014.

[37] Ryu, H. W.; Lee, J. H.; Kang, J. E.; Jin, Y. M.; Park, K. H. J. Korean Soc. Appl. Biol. Chem. 2012, 55, 587.

[38] Park, J. Y.; Yuk, H. J.; Ryu, H. W.; Lim, S. H.; Kim, K. S.; Park, K. H.; Ryu, Y. B. J. Enzyme Inhib. Med. Chem. 2017, 32, 504.

Received June 7, 2019 Accepted June 12, 2019 